\title{
Trade-offs between high yields and greenhouse gas emissions in irrigation wheat cropland in China
}

\author{
Z. L. Cui ${ }^{1, *}$, L. Wu ${ }^{1, *}$, Y. L. Ye ${ }^{2}$, W. Q. Ma ${ }^{3}$, X. P. Chen ${ }^{1}$, and F. S. Zhang ${ }^{1}$ \\ ${ }^{1}$ Center for Resources, Environment and Food Security, China Agricultural University, Beijing 100193, China \\ ${ }^{2}$ College of Resources and Environmental Science, Henan Agricultural University, Zhengzhou 450000, China \\ ${ }^{3}$ College of Resources and Environmental Science, Hebei Agricultural University, Baoding 071001, China \\ *These authors contributed equally to this work.
}

Correspondence to: X. P. Chen (chenxp@cau.edu.cn)

Received: 20 September 2013 - Published in Biogeosciences Discuss.: 29 October 2013

Revised: 20 February 2014 - Accepted: 22 March 2014 - Published: 24 April 2014

\begin{abstract}
Although the concept of producing higher yields with reduced greenhouse gas (GHG) emissions is a goal that attracts increasing public and scientific attention, the tradeoff between high yields and GHG emissions in intensive agricultural production is not well understood. Here, we hypothesize that there exists a mechanistic relationship between wheat grain yield and GHG emission, and that could be transformed into better agronomic management. A total 33 sites of on-farm experiments were investigated to evaluate the relationship between grain yield and GHG emissions using two systems (conventional practice, $\mathrm{CP}$; high-yielding systems, HY) of intensive winter wheat (Triticum aestivum L.) in China. Furthermore, we discussed the potential to produce higher yields with lower GHG emissions based on a survey of 2938 farmers. Compared to the CP system, grain yield was $39 \%\left(2352 \mathrm{~kg} \mathrm{ha}^{-1}\right)$ higher in the HY system, while GHG emissions increased by only $10 \%$, and GHG emission intensity was reduced by $21 \%$. The current intensive winter wheat system with farmers' practice had a median yield and maximum GHG emission rate of $6050 \mathrm{~kg} \mathrm{ha}^{-1}$ and $4783 \mathrm{~kg} \mathrm{CO}_{2}$ eq ha $^{-1}$, respectively; however, this system can be transformed to maintain yields while reducing $\mathrm{GHG}$ emissions by $26 \%\left(6077 \mathrm{~kg} \mathrm{ha}^{-1}\right.$, and $\left.3555 \mathrm{~kg} \mathrm{CO}_{2} \mathrm{eq} \mathrm{ha}^{-1}\right)$. Further, the HY system was found to increase grain yield by $39 \%$ with a simultaneous reduction in $\mathrm{GHG}$ emissions by $18 \%$ (8429 $\mathrm{kg} \mathrm{ha}^{-1}$, and $3905 \mathrm{~kg} \mathrm{CO}_{2} \mathrm{eq} \mathrm{ha}^{-1}$, respectively). In the future, we suggest moving the trade-off relationships and calculations from grain yield and GHG emissions to new measures of productivity and environmental protection using innovative management technologies.
\end{abstract}

\section{Introduction}

Increasing population and consumption are placing unprecedented pressure on agricultural and natural resources (Tilman et al., 2002; Burney et al., 2010; Foley et al., 2011). It has been projected that chemical nitrogen $(\mathrm{N})$ fertilizer consumption will increase by $142-169 \%$ to support a $100-110 \%$ increase in global food crop yields from 2005 to 2050 (Tilman et al., 2011; IFA, 2012). Agricultural intensification of the "green revolution" improved crop productivity while simultaneously increasing environmental costs such as greenhouse gas (GHG) emissions (Tilman et al., 2002; Burney et al., 2010). Agriculture, including fertilizer production, directly contributes $10-12 \%$ of global GHG emissions, and this figure rises to $30 \%$ or more when land conversion and emissions beyond the farm gate are included (Smith et al., 2007). The Intergovernmental Panel on Climate Change (IPCC; 2007) reported that global GHG emissions would need to peak before 2015 and be reduced on the order of 50-85\% (from 2000 levels) by 2050 if dangerous climate change (i.e., a temperature rise $>2.4^{\circ} \mathrm{C}$ ) is to be avoided. These intertwined challenges necessitate a new imperative for global agriculture, where higher grain yields are produced with more efficient use of $\mathrm{N}$ fertilizer and a reduction in both reactive $\mathrm{N}$ losses and $\mathrm{GHG}$ emissions.

Several conceptual frameworks have been proposed to guide efforts that could produce higher yields with reduced input or environmental costs. These frameworks include ecological intensification (Cassman, 1999), an evergreen revolution (Swaminathan, 2000), and eco-efficient agriculture 
(Keating et al., 2010), and they share a view of cropping systems as ecosystems that should be designed to maximize the use of fixed resources (land, light, favorable growing conditions) and optimize the use of agricultural inputs (particularly $\mathrm{N}$ and $\mathrm{P}$ fertilization) to produce high grain yields. Such systems can draw upon features of traditional agricultural knowledge and add new ecological information to the intensification process (Matson et al., 1997; Chen et al., 2011). While there is agreement regarding the need for such improvements, there are only a few examples of how they can be developed and adapted on a large scale and across hundreds of millions of farmers' fields (Carberry et al., 2013).

Wheat production in the North China Plain (NCP) involves some of the most intensive $\mathrm{N}$ applications in the world, and the enrichment of $\mathrm{N}$ in soil, water, and air has created serious environmental problems (Cui et al., 2010; Zhang et al., 2012). For example, the $\mathrm{N}$ applied by farmers of winter wheat in the NCP is often greater than $300 \mathrm{~kg} \mathrm{~N} \mathrm{ha}^{-1}$ (Cui et al., 2010), even though results from region-wide experiments have demonstrated that the optimal $\mathrm{N}$ rate is $128 \mathrm{~kg} \mathrm{Nha}^{-1}$ (Cui et al., 2008). This overuse of $\mathrm{N}$ fertilizer over the past 10 years has not increased wheat yield, with stagnation at $\sim 4573 \mathrm{~kg} \mathrm{ha}^{-1}$ with national average (mean grain yield from 2003 to 2012, FAO, 2013). In contrast, in previous high-yield studies in this region, high wheat yield $\left(\geq 9000 \mathrm{~kg} \mathrm{ha}^{-1}\right)$ was achieved by optimizing the wheat canopy and using favorable management practices to maximize both the quantity and quality of the wheat canopy (Meng et al., 2013).

Recent studies have shown great promise for increasing $\mathrm{N}$-use efficiency and grain yield in maize production by integrating crop and N management (Chen et al., 2011; Grassini and Cassman, 2012). Here, we hypothesize that there exists a mechanistic relationship between wheat grain yield and GHG emission, and that could be transformed into better combining improved crop management technologies with optimal $\mathrm{N}$ management. Two groups of experiments with different on-farm $\mathrm{N}$ level management systems were conducted in the key winter wheat growing region of northern China. A conventional practice (CP) plot was managed based on farmers' current practices with a yield of approximately $6000 \mathrm{~kg} \mathrm{ha}^{-1}$; on a high-yield (HY) plot, an integrated soil-crop system management approach was applied to close the yield gap and maintain the grain yield at approximately $8500 \mathrm{~kg} \mathrm{ha}^{-1}$. We evaluated the trade-off relationships between crop productively and GHG emission for the CP and HY systems. We discuss the potential for shifting the focus of the current farming system to new productivity and environmental protection values to produce higher yields with reduced GHG emissions.

\section{Methods and materials}

All experiments were conducted on farm fields at 33 sites in 31 counties from 2007 to 2008 , including 15 sites in
Henan province ( $\mathrm{S} 1$ to $\mathrm{S} 15), 4$ sites in Hebei province (S16 to S19), 12 sites in Shandong province (S20 to S31), and 2 sites in Shaanxi province (S32 to S33, Supplement Fig. S1 and Table S1). The climate in the experimental region is a warm, temperate, sub-humid, continental monsoon climate with cold winters and hot summers. The annual cumulative mean temperature for days with mean temperatures above $10^{\circ} \mathrm{C}$ is $4000-5000^{\circ} \mathrm{C}$, and the annual frost-free period is 175 to 220 days. Annual precipitation is 500 to $700 \mathrm{~mm}$, with approximately $30-40 \%$ of the rainfall occurring during the winter wheat growing season (from the beginning of October to middle of June). The amount and distribution of rainfall vary widely from year to year, and are affected by the continental monsoon climate. The soil types were mainly calcareous fluvo-aquic, yellow brown, cinnamon, yellow cinnamon, meadow sanne, and yellow soils. Details of site coordinates, average annual precipitation, soil texture, soil types and some soil properties are shown in Supplement Table S1.

\subsection{On-farm field experiments: design, crop management, and sampling procedures}

Both systems (CP and HY) were tested at each of the 33 sites under four or five $\mathrm{N}$ treatments. Five $\mathrm{N}$ treatments in 15 sites in Henan province included no $\mathrm{N}$ as a control (CK), and low (50\% of median), median, high ( $150 \%$ of median), and very high ( $200 \%$ of median) treatments. Four $\mathrm{N}$ treatments at the other 18 sites included no $\mathrm{N}$ as a control (CK), and low (50\% of median), median, and high ( $150 \%$ of median). The amount of $\mathrm{N}$ fertilizer for the median $\mathrm{N}$ treatment was recommended by local agricultural extension employees based on experience. Detailed information of $\mathrm{N}$ application rates for the 33 sites is shown in Table 1.

For both conventional practice (CP) and high-yield (HY) systems, one-third of granular urea $\left(\mathrm{CO}\left(\mathrm{NH}_{2}\right)_{2}\right)$ is applied by broadcasting at the time of sowing, and the remainder is applied at the stem elongation stage prior to irrigation. Depending on the weather, winter wheat typically receives three irrigations (about $90 \mathrm{~mm}$ per time): one before winter, a second at the stem elongation stage, and another around the anthesis stage. Although the volume of irrigation was not precisely measured for every plot and site, the values were similar for each system at every site. For the CP system, experiments were managed using each individual farmer's current crop management practices, except for $\mathrm{N}$ fertilizer application rate. In the HY system, local agronomists recommended new varieties with resistance to disease, environmental stress, and lodging that also had the potential for high yields. These new varieties varied across experimental sites. In addition, the better combinations of planting date and plant populations based on local weather (e.g., mean temperatures) were used to optimize the crop canopy, and make maximum use of regional environmental resources (e.g., light and temperature). Compared to the HY system, most farmers' fields used later sowing and used more seeds. Finally, in the HY system, 
Table 1. $\mathrm{N}$ application rate and wheat grain yield for different $\mathrm{N}$ application rates and the two systems. $\mathrm{N}$ application rate including no $\mathrm{N}$ as a control $(0 \mathrm{~N}), 50 \%$ of median $\mathrm{N}$ rate $(50 \% \mathrm{~N}), 100 \%$ of median $\mathrm{N}$ rate $(100 \% \mathrm{~N}), 150 \%$ of median $\mathrm{N}$ rate $(150 \% \mathrm{~N})$, and $200 \%$ of median $\mathrm{N}$ rate $(50 \% \mathrm{~N})$. The systems included a conventional practice $(\mathrm{CP})$ and a high-yielding system $(\mathrm{HY})$.

\begin{tabular}{|c|c|c|c|c|c|c|c|c|c|c|c|c|c|c|c|c|c|c|c|c|}
\hline \multirow[t]{3}{*}{ Sites } & \multicolumn{10}{|c|}{$\mathrm{CP}$} & \multicolumn{10}{|c|}{ HY } \\
\hline & \multicolumn{5}{|c|}{$\mathrm{N}$ rate $\left(\mathrm{kg} \mathrm{N} \mathrm{ha}^{-1}\right)$} & \multicolumn{5}{|c|}{ Grain yield $\left(\mathrm{kg} \mathrm{ha}^{-1}\right)$} & \multicolumn{5}{|c|}{$\mathrm{N}$ rate $\left(\mathrm{kg} \mathrm{N} \mathrm{ha}^{-1}\right)$} & \multicolumn{5}{|c|}{ Grain yield $\left(\mathrm{kg} \mathrm{ha}^{-1}\right)$} \\
\hline & 0 & $50 \%$ & $100 \%$ & $150 \%$ & $200 \%$ & 0 & $50 \%$ & $100 \%$ & $150 \%$ & $200 \%$ & 0 & $50 \%$ & $100 \%$ & $150 \%$ & $200 \%$ & 0 & $50 \%$ & $100 \%$ & $150 \%$ & $200 \%$ \\
\hline S1 & 0 & 105 & 210 & 315 & 420 & 3993 & 5619 & 5757 & 5659 & 5822 & 0 & 105 & 210 & 315 & 420 & 6081 & 6962 & 7233 & 7390 & 7356 \\
\hline S2 & 0 & 105 & 210 & 315 & 420 & 3493 & 5619 & 5758 & 5659 & 5822 & 0 & 105 & 210 & 315 & 420 & 6008 & 8392 & 9389 & 9030 & 8429 \\
\hline S3 & 0 & 105 & 210 & 315 & 420 & 3794 & 5654 & 5759 & 6937 & 6673 & 0 & 105 & 210 & 315 & 420 & 6967 & 8476 & 9121 & 9163 & 8855 \\
\hline S4 & 0 & 105 & 210 & 315 & 420 & 4845 & 5387 & 5760 & 5672 & 5617 & 0 & 105 & 210 & 315 & 420 & 6495 & 7387 & 8379 & 8252 & 8263 \\
\hline S5 & 0 & 105 & 210 & 315 & 420 & 4875 & 5485 & 5761 & 6390 & 6240 & 0 & 105 & 210 & 315 & 420 & 4920 & 6510 & 8480 & 8795 & 8310 \\
\hline S6 & 0 & 105 & 210 & 315 & 420 & 3867 & 5205 & 5762 & 5167 & 4917 & 0 & 105 & 210 & 315 & 420 & 6168 & 7179 & 8215 & 8345 & 7484 \\
\hline S7 & 0 & 105 & 210 & 315 & 420 & 4059 & 5185 & 5763 & 6285 & 5869 & 0 & 105 & 210 & 315 & 420 & 4319 & 6710 & 7697 & 7627 & 7151 \\
\hline S8 & 0 & 105 & 210 & 315 & 420 & 3884 & 5122 & 5764 & 5746 & 5262 & 0 & 105 & 210 & 315 & 420 & 4546 & 5431 & 7680 & 8547 & 7775 \\
\hline S9 & 0 & 105 & 210 & 315 & 420 & 3904 & 4565 & 5765 & 5499 & 5465 & 0 & 105 & 210 & 315 & 420 & 6649 & 7989 & 8306 & 8783 & 8389 \\
\hline $\mathrm{S} 10$ & 0 & 105 & 210 & 315 & 420 & 3214 & 4504 & 5766 & 5781 & 5615 & 0 & 105 & 210 & 315 & 420 & 3914 & 6005 & 8218 & 8148 & 7595 \\
\hline S11 & 0 & 90 & 180 & 270 & 360 & 4876 & 5746 & 5767 & 5815 & 5770 & 0 & 90 & 180 & 270 & 360 & 6612 & 8308 & 8817 & 9644 & 9317 \\
\hline $\mathrm{S} 12$ & 0 & 90 & 180 & 270 & 360 & 4268 & 4908 & 5768 & 5127 & 4598 & 0 & 90 & 180 & 270 & 360 & 6016 & 7583 & 8216 & 8458 & 6992 \\
\hline $\mathrm{S} 13$ & 0 & 105 & 210 & 315 & 420 & 4035 & 5107 & 5769 & 5385 & 5120 & 0 & 105 & 210 & 315 & 420 & 5716 & 7320 & 8219 & 8011 & 7160 \\
\hline $\mathrm{S} 14$ & 0 & 105 & 210 & 315 & 420 & 4200 & 5256 & 5770 & 5989 & 5912 & 0 & 105 & 210 & 315 & 420 & 6556 & 7290 & 8923 & 8067 & 7812 \\
\hline S15 & 0 & 105 & 210 & 315 & 420 & 2667 & 4272 & 5771 & 5070 & 5208 & 0 & 105 & 210 & 315 & 420 & 5897 & 6972 & 8026 & 9212 & 8644 \\
\hline S16 & 0 & 90 & 180 & 270 & & 5053 & 6768 & 7784 & 7078 & & 0 & 90 & 180 & 270 & & 5744 & 7747 & 8959 & 9057 & \\
\hline S17 & 0 & 90 & 180 & 270 & & 4527 & 5664 & 6095 & 6068 & & 0 & 113 & 225 & 338 & & 6311 & 8176 & 9081 & 9206 & \\
\hline S18 & 0 & 90 & 180 & 270 & & 4067 & 5415 & 5715 & 5889 & & 0 & 90 & 180 & 270 & & 5476 & 7398 & 8501 & 7743 & \\
\hline S19 & 0 & 113 & 225 & 338 & & 5075 & 5839 & 6510 & 6162 & & 0 & 113 & 225 & 338 & & 6160 & 7537 & 9032 & 8531 & \\
\hline $\mathrm{S} 20$ & 0 & 90 & 180 & 270 & & 5028 & 5494 & 5998 & 6038 & & 0 & 113 & 225 & 338 & & 6803 & 7718 & 8541 & 8029 & \\
\hline $\mathrm{S} 21$ & 0 & 105 & 210 & 315 & & 5000 & 5997 & 6231 & 6251 & & 0 & 105 & 210 & 315 & & 7374 & 9025 & 9580 & 9628 & \\
\hline S22 & 0 & 105 & 210 & 315 & & 5148 & 6175 & 6525 & 6225 & & 0 & 105 & 210 & 315 & & 7067 & 7632 & 9106 & 9138 & \\
\hline $\mathrm{S} 23$ & 0 & 90 & 180 & 270 & & 4594 & 5531 & 5846 & 5972 & & 0 & 105 & 210 & 315 & & 6507 & 8400 & 9343 & 9324 & \\
\hline $\mathrm{S} 24$ & 0 & 90 & 180 & 270 & & 4624 & 5378 & 6001 & 6134 & & 0 & 105 & 210 & 315 & & 7392 & 7982 & 8863 & 8901 & \\
\hline S25 & 0 & 105 & 210 & 315 & & 4496 & 5367 & 6169 & 6002 & & 0 & 105 & 210 & 315 & & 6151 & 6449 & 8601 & 8235 & \\
\hline S26 & 0 & 113 & 225 & 338 & & 4098 & 5004 & 5908 & 5699 & & 0 & 113 & 225 & 338 & & 6540 & 7454 & 8455 & 8423 & \\
\hline S27 & 0 & 105 & 210 & 315 & & 4813 & 5456 & 6174 & 5853 & & 0 & 113 & 225 & 338 & & 6996 & 7781 & 8730 & 8482 & \\
\hline $\mathrm{S} 28$ & 0 & 105 & 210 & 315 & & 4742 & 5402 & 5927 & 5754 & & 0 & 113 & 225 & 338 & & 7209 & 7576 & 9172 & 8420 & \\
\hline $\mathrm{S} 29$ & 0 & 90 & 180 & 270 & & 4883 & 5383 & 5944 & 5509 & & 0 & 113 & 225 & 338 & & 6658 & 7617 & 8960 & 8236 & \\
\hline S30 & 0 & 105 & 210 & 315 & & 4138 & 5086 & 5623 & 5094 & & 0 & 105 & 210 & 315 & & 7281 & 8006 & 8924 & 8955 & \\
\hline S31 & 0 & 105 & 210 & 315 & & 4639 & 5465 & 6187 & 6357 & & 0 & 105 & 210 & 315 & & 6499 & 7355 & 8107 & 8104 & \\
\hline S32 & 0 & 90 & 180 & 270 & & 5345 & 5507 & 6460 & 6435 & & 0 & 90 & 180 & 270 & & 7683 & 8039 & 9443 & 9395 & \\
\hline S33 & 0 & 90 & 180 & 270 & & 4250 & 4420 & 6223 & 5839 & & 0 & 90 & 180 & 270 & & 5339 & 6774 & 9521 & 9147 & \\
\hline mean & 0 & 101 & 201 & 302 & 412 & 4378 & 5363 & 5993 & 5895 & 5594 & 0 & 104 & 208 & 312 & 412 & 6244 & 7490 & 8662 & 8619 & 7969 \\
\hline
\end{tabular}

we improved sowing quality by careful management to foster strong individual plants and make them uniform, creating a lodging-resistant architecture in the crop canopy. Weeds were well controlled with the use of spray herbicides and manual pulling. Pest and disease stress were controlled using spray insecticide and fungicide before the stem elongation stage and after anthesis. No obvious water, weed, pest, or disease stress was observed during the wheat-growing season for both CP and HY system.

A randomized complete block design was employed in three replications with plots measuring $>40 \mathrm{~m}^{2}$. All plots received approximately $90 \mathrm{~kg} \mathrm{P}_{2} \mathrm{O}_{5} \mathrm{ha}^{-1}$ as calcium superphosphate $\left(\mathrm{Ca}\left(\mathrm{H}_{2} \mathrm{PO}_{4}\right)_{2} \cdot \mathrm{H}_{2} \mathrm{O}\right)$ and about $60 \mathrm{~kg} \mathrm{~K}_{2} \mathrm{O}^{-1}$ as potassium chloride $\left(\mathrm{K}_{2} \mathrm{SO}_{4}\right)$ before planting.

At maturity, three separate areas (each 2-3 $\mathrm{m}^{2}$ ) were harvested manually. All plant samples were oven dried at $70^{\circ} \mathrm{C}$ in a forced-draft oven to a constant weight, weighed, and yields were adjusted to $125 \mathrm{~g} \mathrm{~kg}^{-1}$ moisture content.

\subsection{Farmers' survey}

With the key winter wheat growing region of northern China from 2004 to 2009, approximately 2-8 typical townships were randomly selected in each county, and 4-6 typical villages were randomly selected in each township. Out of these, 8-10 farmers were randomly questioned regarding their choice of fertilizer, application rate, and grain yield in the past year. Data required included fertilizer production, $\mathrm{N}$ content, fertilizer application rate and grain yield. For grain yield and $\mathrm{N}$ application, only a few observations $(<5 \%)$ fell outside the normally expected ranges of the entire data set. However, considering the great variation in each parameter among fields, we treated the upper and lower 2.5 percentiles of the data as outliers (Fig. S2). By considering all of the survey data and removing the top and bottom $2.5 \%$ of respondents, a total of 2938 (39 counties in 5 provinces) were evaluated in this study. 


\subsection{Data analysis}

For each experiment, the total GHG emissions, including $\mathrm{CO}_{2}, \mathrm{CH}_{4}$, and $\mathrm{N}_{2} \mathrm{O}$ during the whole life cycle of wheat production, were divided into three components: (1) those emitted during $\mathrm{N}$ fertilizer application, including direct and indirect $\mathrm{N}_{2} \mathrm{O}$ emissions, which can be calculated based on the empirical $\mathrm{N}$ loss model (see below); (2) those released during $\mathrm{N}$ fertilizer production and transportation; and (3) those emitted during the production and transportation of pesticides to the farm gate and diesel fuel use in farming operations such as sowing, tilling, irrigation and harvesting (Supplement Table S2). The impact of the GHG emissions was calculated as $\mathrm{CO}_{2}$ eq. The $100 \mathrm{yr}$ global warming potential (GWP) of $\mathrm{CH}_{4}$ and $\mathrm{N}_{2} \mathrm{O}$ are 25 and 298 times the intensity of $\mathrm{CO}_{2}$ on a mass basis, respectively (Forster et al., 2007). The soil $\mathrm{CO}_{2}$ flux as a contributor to global warming potential was not included in our analysis, because net flux has been estimated to contribute $<1 \%$ of the GHG emissions from agriculture on a global scale (Smith et al., 2007). The change in soil organic carbon content was also not included in our analysis because it was difficult to detect such a small magnitude of change over a short time (Conant et al., 2010).

We used values in the published literature to simulate the relationship between $\mathrm{N}$ loss and $\mathrm{N}$ application rate and to estimate GHG emissions from $\mathrm{N}$ fertilization. Total $\mathrm{N}_{2} \mathrm{O}$ emissions included both direct and indirect emissions. Indirect emissions were estimated using a method of the IPCC (IPCC, 2006), where 1 and $0.75 \%$ of ammonia $\left(\mathrm{NH}_{3}\right)$ volatilization and nitrate $\left(\mathrm{NO}_{3}^{-}\right)$leaching are lost as $\mathrm{N}_{2} \mathrm{O}$, respectively. The $\mathrm{N}$ losses were calculated based on an empirical model that employs the following equations from Supplement Fig. S3:

Direct $\mathrm{N}_{2} \mathrm{O}$ emissions $\left(\mathrm{kg} \mathrm{N} \mathrm{ha}^{-1}\right)=0.33 \exp (0.0054 \mathrm{~N}$ rate $)$, (1)

$\mathrm{NH}_{3}$ volatilization $\left(\mathrm{kg} \mathrm{N} \mathrm{ha}^{-1}\right)=0.17 \mathrm{~N}$ rate -4.95 ,

$\mathrm{N}$ leaching $\left(\mathrm{kg} \mathrm{N} \mathrm{ha}^{-1}\right)=2.7 \exp (0.0088 \mathrm{~N}$ rate $)$.

The system boundaries were set using scales in the life cycle from production inputs (such as fertilizers and pesticides), delivery of inputs to the farm gates, farming operations, and wheat harvesting. Using the emission factors for all agricultural inputs given in Supplement Table S2, we calculated total GHG per unit area, expressed as $\mathrm{kg} \mathrm{CO}_{2}$ eq ha ${ }^{-1}$, and the GHG intensity, expressed as $\mathrm{kg} \mathrm{CO}_{2} \mathrm{eq} \mathrm{Mg}^{-1}$ grain.

The relationship between wheat grain yield and GHG emissions at each of the 33 sites in the two cropping systems with either four or five $\mathrm{N}$ treatments was determined using the IPNI Crop Nutrient Response Tool (http://nane.ipni. net/article/NANE-3068) and the NLIN procedure in SAS (SAS Institute, 1998). We evaluated five models: quadratic, quadratic with plateau, linear with plateau, square root, and spherical with plateau. In most cases, all five models significantly fit the data $(P<0.01)$, and had similar coefficients of determination $\left(R^{2}\right)$. Considering the continuity and smooth simulation, we chose the spherical with plateau model for all of the sites (Cerrato and Blackmer, 1990). We determined the minimum GHG emissions needed to achieve maximum grain yield as the inflection point of the curve (Cerrato and Blackmer, 1990).

\section{Results}

Considering all 33 locations, wheat grain yield averaged $5993 \mathrm{~kg} \mathrm{ha}^{-1}$ in the median $\mathrm{N}$ treatments $\left(201 \mathrm{~kg} \mathrm{Nha}^{-1}\right)$ of CP systems. For the HY system, grain yield averaged $8662 \mathrm{~kg} \mathrm{ha}^{-1}\left(208 \mathrm{~kg} \mathrm{Nha}^{-1}\right)$, which was $45 \%$ $\left(\sim 2669 \mathrm{~kg} \mathrm{ha}^{-1}\right)$ higher than that of the CP systems. Correspondingly, grain yield with no $\mathrm{N}$ control in the HY system averaged $6244 \mathrm{~kg} \mathrm{ha}^{-1}$, which was $43 \%\left(\sim 1866 \mathrm{~kg} \mathrm{ha}^{-1}\right)$ higher than a grain yield of $4378 \mathrm{~kg} \mathrm{ha}^{-1}$ from the CP system (Table 1). Although a large difference in grain yield was observed between the CP and HY systems, there were no differences in soil properties and soil type (Supplement Table S1).

\subsection{Relationship between wheat yield and GHG emissions for different management systems}

Pooling data from all 33 experimental sites receiving either four or five $\mathrm{N}$ treatments, the relationship between wheat grain yield and GHG emission fit a spherical-plateau model $(P<0.001$; Fig. 1$)$. The minimum GHG emissions needed to achieve maximum grain yield was 3555 and $3905 \mathrm{~kg} \mathrm{CO}_{2} \mathrm{eq} \mathrm{Mg}^{-1}$ for the CP and HY system. In contrast, the corresponding grain yield for the HY system was $8429 \mathrm{~kg} \mathrm{ha}^{-1}, 39 \%$ greater than the $6077 \mathrm{~kg} \mathrm{ha}^{-1}$ for the CP system. The GHG emission intensity reduced by $21 \%$ from $585 \mathrm{~kg} \mathrm{CO}_{2}$ eq $\mathrm{Mg}^{-1}$ for HY system to $463 \mathrm{~kg} \mathrm{CO}_{2} \mathrm{eq} \mathrm{Mg}^{-1}$ for CP system.

Large site-specific variations in GHG emission and grain yield were observed across the 33 experimental sites (Table 2). Calculated minimum GHG emissions needed to achieve maximum grain yield for the $\mathrm{CP}$ system by spherical with plateau model ranged from 2736 (S11) to $5475 \mathrm{~kg} \mathrm{CO}_{2} \mathrm{eq} \mathrm{ha}^{-1}$ (S9), similar to the HY system, which ranged from 3055 (S12) to $5476 \mathrm{~kg} \mathrm{CO}_{2} \mathrm{eq} \mathrm{ha}^{-1}$ (S15) (Table 2). The corresponding maximum yield for the CP system ranged from 5012 to $7421 \mathrm{~kg} \mathrm{ha}^{-1}$, whereas in the HY system, these values ranged from 7314 to $9598 \mathrm{Mg} \mathrm{ha}^{-1}$ (Table 2). As a result, GHG emission intensity ranged from 456 to $998 \mathrm{~kg} \mathrm{CO}_{2} \mathrm{eq} \mathrm{Mg}^{-1}$ for the CP system and from 343 to $652 \mathrm{~kg} \mathrm{CO}_{2} \mathrm{eq} \mathrm{Mg}^{-1}$ for the HY system (Table 2).

\subsection{Opportunity to produce higher yields with reduced GHG emissions}

Based on a survey of farmers' practices for 2938 farmers, the $\mathrm{N}$ application rate averaged $284 \mathrm{~kg} \mathrm{Nha}^{-1}$ and ranged from 77 to $573 \mathrm{~kg} \mathrm{Nha}^{-1}$; the corresponding grain yield averaged $6050 \mathrm{~kg} \mathrm{ha}^{-1}$ with a range from 
Table 2. The minimum GHG emissions needed to achieve maximum grain yield and the corresponding yields for a conventional practice (CP) and a high-yielding system (HY).

\begin{tabular}{|c|c|c|c|c|c|c|}
\hline \multirow[t]{2}{*}{ Sites } & \multicolumn{3}{|c|}{$\mathrm{CP}$ system } & \multicolumn{3}{|c|}{ HY system } \\
\hline & $\begin{array}{c}\text { Mini. GHG } \\
\text { emission } \\
\mathrm{kg} \mathrm{CO}_{2} \text { eq ha }\end{array}$ & $\begin{array}{c}\text { Max. } \\
\text { yield } \\
\mathrm{kg} \mathrm{ha}^{-1}\end{array}$ & $\begin{array}{c}\text { GHG emission } \\
\text { intensity } \\
\mathrm{kg} \mathrm{CO}_{2} \text { eq } \mathrm{Mg}^{-1}\end{array}$ & $\begin{array}{c}\text { Mini. GHG } \\
\text { emission } \\
\mathrm{kg} \mathrm{CO}_{2} \text { eq ha }^{-1}\end{array}$ & $\begin{array}{l}\text { Max. } \\
\text { yield } \\
\mathrm{kg} \mathrm{ha}^{-1}\end{array}$ & $\begin{array}{l}\text { GHG emission } \\
\text { intensity } \\
\mathrm{kg} \mathrm{CO}_{2} \text { eq } \mathrm{Mg}^{-1}\end{array}$ \\
\hline $\mathrm{S} 1$ & 3117 & 5761 & 541 & 3322 & 7314 & 454 \\
\hline S2 & 3380 & 5771 & 586 & 3403 & 8961 & 380 \\
\hline S3 & 4295 & 6797 & 632 & 3338 & 9039 & 369 \\
\hline S4 & 3448 & 5875 & 587 & 3929 & 8286 & 474 \\
\hline S5 & 4398 & 6296 & 698 & 4556 & 8603 & 530 \\
\hline S6 & 2932 & 5277 & 556 & 3709 & 7988 & 464 \\
\hline S7 & 3801 & 6156 & 617 & 3920 & 7504 & 522 \\
\hline S8 & 3599 & 5660 & 636 & 5326 & 8170 & 652 \\
\hline S9 & 5475 & 5487 & 998 & 3444 & 8492 & 406 \\
\hline S10 & 4661 & 5715 & 816 & 4687 & 8003 & 586 \\
\hline S11 & 2736 & 5806 & 471 & 4799 & 9448 & 508 \\
\hline S12 & 2982 & 5012 & 595 & 3055 & 7888 & 387 \\
\hline $\mathrm{S} 13$ & 3249 & 5410 & 601 & 3280 & 7796 & 421 \\
\hline S14 & 3798 & 6119 & 621 & 3820 & 8210 & 465 \\
\hline S15 & 4610 & 5136 & 898 & 5476 & 8890 & 616 \\
\hline S16 & 3387 & 7421 & 456 & 3847 & 9059 & 425 \\
\hline S17 & 3143 & 6082 & 517 & 3742 & 9141 & 409 \\
\hline S18 & 3187 & 5814 & 548 & 3310 & 8106 & 408 \\
\hline S19 & 3650 & 6305 & 579 & 3992 & 8741 & 457 \\
\hline S20 & 3686 & 6033 & 611 & 3639 & 8259 & 441 \\
\hline S21 & 3026 & 6232 & 486 & 3295 & 9598 & 343 \\
\hline S22 & 2929 & 6367 & 460 & 4645 & 9189 & 505 \\
\hline S23 & 3050 & 5900 & 517 & 3537 & 9328 & 379 \\
\hline S24 & 3811 & 6127 & 622 & 4305 & 8917 & 483 \\
\hline S25 & 3763 & 6068 & 620 & 4520 & 8380 & 539 \\
\hline S26 & 3967 & 5781 & 686 & 4301 & 8459 & 508 \\
\hline S27 & 3591 & 5975 & 601 & 4000 & 8576 & 466 \\
\hline S28 & 3515 & 5815 & 604 & 4080 & 8685 & 470 \\
\hline S29 & 3084 & 5695 & 542 & 3851 & 8539 & 451 \\
\hline S30 & 3101 & 5348 & 580 & 4258 & 8977 & 474 \\
\hline S31 & 4315 & 6346 & 680 & 3966 & 8119 & 488 \\
\hline S32 & 4197 & 6475 & 648 & 4184 & 9459 & 442 \\
\hline S33 & 3986 & 5973 & 667 & 4341 & 9397 & 462 \\
\hline
\end{tabular}

3.44 to $8.31 \mathrm{Mg} \mathrm{ha}^{-1}$ (Fig. 2, Supplement Fig. S2). The calculated GHG emissions averaged $4783 \mathrm{~kg} \mathrm{CO}_{2}$ eq ha $^{-1}$ (Fig. 2), of which $1183 \mathrm{~kg} \mathrm{CO}_{2} \mathrm{eq} \mathrm{ha}^{-1}$ was attributable to field management (e.g., irrigation, tillage, and harvesting), $1270 \mathrm{~kg} \mathrm{CO}_{2} \mathrm{eq} \mathrm{ha}^{-1}$ was from $\mathrm{N}$ fertilization, and 2330 originated from $\mathrm{N}$ production and transport. Calculated $\mathrm{GHG}$ emission intensity averaged $807 \mathrm{~kg} \mathrm{CO}_{2} \mathrm{eq} \mathrm{Mg}^{-1}$. The GHG emissions ranged from 2106 to $10757 \mathrm{~kg} \mathrm{CO}_{2} \mathrm{eq} \mathrm{ha}^{-1}$ with a variance of $38 \%$, whereas GHG emission intensity ranged from 382 to $1795 \mathrm{~kg} \mathrm{CO}_{2}$ eq ha $^{-1}$ with a variance of $39 \%$ (Fig. 2).

Compared to average farmers' practices (point A), the minimum GHG emissions needed to achieve a maximum grain yield for CP systems (point B) was reduced by $26 \%$ from 4783 to $3555 \mathrm{~kg} \mathrm{CO}_{2} \mathrm{eq} \mathrm{ha}^{-1}$ without any losses in yield (pathway from A to B, Fig. 2). The GHG emission intensity of point $\mathrm{B}$ was $585 \mathrm{~kg} \mathrm{CO}_{2} \mathrm{eq} \mathrm{ha}^{-1}$, which was only $74 \%$ of current practices (point A). With the HY system, grain yield increased to $8429 \mathrm{~kg} \mathrm{ha}^{-1}$ (or $39 \%$ compared to point A) with a GHG emission reduction of $18 \%(\sim 3905 \mathrm{~kg}$ $\mathrm{CO}_{2}$ eq ha ${ }^{-1}$ ) (pathway A to $\mathrm{C}$, Fig. 2). As a result, the GHG emission intensity for point $\mathrm{C}$ reduced by $41 \%$ from $807 \mathrm{~kg} \mathrm{CO}_{2} \mathrm{eq} \mathrm{Mg}^{-1}$ for point A to $463 \mathrm{~kg} \mathrm{CO}_{2} \mathrm{eq} \mathrm{Mg}^{-1}$, for HY point $\mathrm{C}$.

If food crop yields need to be increased by $100-110 \%$ in the future (Tilman et al. 2011), a wheat yield of $12 \mathrm{Mg} \mathrm{ha}^{-1}$ will be necessary in China. This would require approximately $292 \mathrm{~kg} \mathrm{~N} \mathrm{ha}^{-1}$ (Yue et al., 2012), close to the 


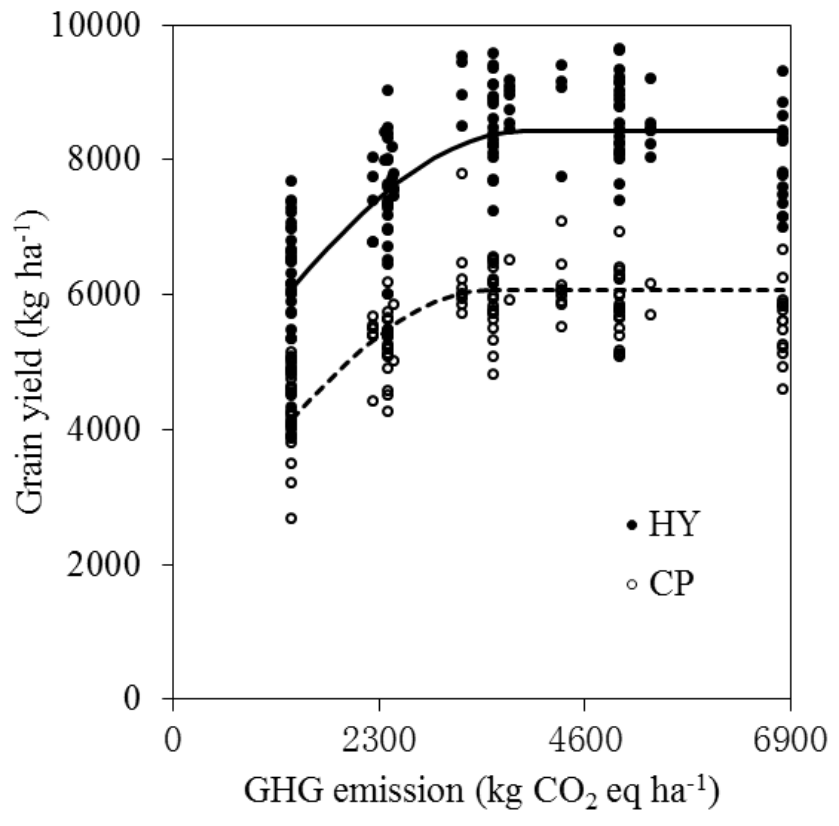

Fig. 1. The relationship between GHG emissions and grain yield for the CP (small circle and dashed line) and the HY (dot and solid line) system. Data were pooled from 33 sites of on-farm experiments for $\mathrm{CP}$ and HY systems. The relationship between GHG emissions and grain yield was $Y=1940+4137\left(3 X / 7110-0.5(X / 3555)^{3}\right), X<$ 3555; $Y=6077, X>3555\left(R^{2}=0.75, P<0.001\right)$ for CP system, and $Y=3845+4583\left(3 X / 7810-0.5(X / 3905)^{3}\right), X<3905 ; Y=$ $8429, X>3905\left(R^{2}=0.68, P<0.001\right)$ for HY system.

$284 \mathrm{~kg} \mathrm{Nha}^{-1}$ total $\mathrm{N}$ rate used under current practices. This indicates that the target yield of $12 \mathrm{Mg} \mathrm{ha}^{-1}$ could be achieved using current $\mathrm{N}$ application rates if $\mathrm{N}$ losses can be controlled. Thus, GHG emissions from $\mathrm{N}$ fertilizer would be similar to or less than the level associated with current practices. A new level for productivity and environmental sustainability should be created for the pathway from point $\mathrm{C}$ to D in Fig. 4.

\section{Discussions}

While the concept of producing higher yields with less GHG emissions as a goal has been widely debated, studies on crop productively and GHG emission have been notably disconnected in the past (Tilman et al., 2002; Burney et al., 2010; Carberry et al., 2013). Generally, the increasing of $\mathrm{N}$ application rate cannot promise a substantial increase in crop productivity because of diminishing returns (Cassman et al., 2003) but increase GHG emission (McSwiney and Robertson, 2005; Hoben et al., 2011; Van Groenigen et al., 2010; Cui et al., 2013ab). Previous studies have focused on how to optimize $\mathrm{N}$ management (e.g., appropriate source, timing, placement, or product) to enhance crop recovery of applied $\mathrm{N}$ and reduce $\mathrm{N}$ losses and GHG emissions (Snyder et al.,

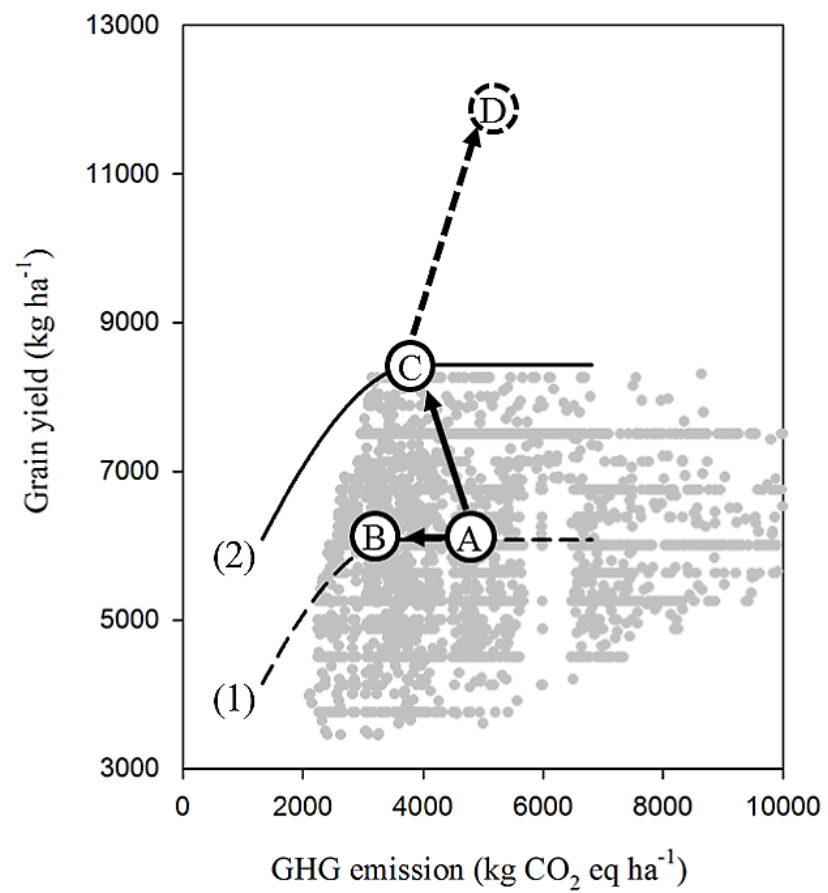

Fig. 2. A stylized grain yield-GHG emission framework demonstrating three pathways to produce higher yields with less GHG emissions. The gray dots represent grain yields and GHG emissions for the 2938 farmers surveyed. The line of dashed line (1) and solid line (2) mean relationship between grain yield and GHG emission for $\mathrm{CP}$ and $\mathrm{HY}$ system, respectively. Point $\mathrm{A}$ is the average for all farmers; points B and C are the minimum GHG emissions for maximum grain yield with the $\mathrm{CP}$ and $\mathrm{HY}$ system, respectively (the details are shown in Fig. 3); and point D represents the target of $12 \mathrm{Mg} \mathrm{ha}^{-1}$ of wheat grain yield in the future.

2009; Millaret et al., 2010; Cui et al., 2013a, b). For winter wheat systems in China, an in-season root-zone $\mathrm{N}$ management strategy can reduce the $\mathrm{N}$ application rate by $61 \%$ from $325 \mathrm{~kg} \mathrm{Nha}^{-1}$ to $128 \mathrm{~kg} \mathrm{Nha}^{-1}$ compared to current practices, resulting in an large decrease in GHG emissions from $\mathrm{N}$ fertilizer with no loss in wheat grain yield (Cui et al., 2013b). This result is represented by the pathway from point A to B in Fig. 2. Although these practices represent a large step forward, increasing rather than merely maintaining grain yield, they also present a fundamental challenge.

In intensive cropping systems, the more efficient cycling of $\mathrm{N}$ depends on environmental management interactions that influence the balance and rate of microbial processes (e.g., nitrification and denitrification) and transport among plant, soil and environments (e.g., air and water) (Robertson and Vitousek, 2009). When a high-yield system was adopted in a previous study, crop health, insect and weed management, moisture and temperature regimes, supplies of nutrients other than $\mathrm{N}$, and use of the best-adapted cultivar or hybrid all contributed to more efficient uptake of available $\mathrm{N}$ and greater conversion of plant $\mathrm{N}$ to grain yield, therefore 
reducing reactive $\mathrm{N}$ losses and $\mathrm{GHG}$ emissions (Cassman et al., 2003; Cui et al., 2013b).

In the HY system of the present study, the better combination of adopted varieties, planting data, and planting quality was determined to optimize the crop canopy, and this maximized the use of regional environmental resources (e.g., light, temperature). Yields were increased by $39 \%$, and GHG emission intensity was reduced by $41 \%$, compared to current practices. Within the CP system, late sowing and the use of too many seeds often results in excessively large canopies and weak individuals, which lead to high susceptibility to lodging, low efficiency of light capture, small spikes, small grains, and consequently low yields (Xu et al., 2013).

To the best of our knowledge, this is the first on-farm study to report the relationship between wheat grain yields and total GHG emissions. Grain yield increased with increasing GHG emissions before reaching the maximum yield, with the lowest GHG emissions achieved when emission intensity decreased, indicating a trade-off relationship between high yields and GHG emissions (Figs. 2 and 4 S). In this study, grain yield in the HY system increased by $39 \%$ while GHG emissions increased by only $10 \%$, and GHG emission intensity was reduced by $21 \%$, compared to the CP system. This new paradigm for productivity and environmental sustainability is currently being extended to farmers throughout the cereal crop production area in China, but it also appears to be relevant for other high-yield cropping systems outside China. For example, in UK wheat production, GHG emission intensity is $313 \mathrm{~kg} \mathrm{CO}_{2} \mathrm{eq} \mathrm{Mg}^{-1}$ of grain, and grain yield is about $10 \mathrm{Mg} \mathrm{ha}^{-1}$ (Berry et al., 2008). Maize in central Nebraska achieves higher grain yields $\left(13.2 \mathrm{Mg} \mathrm{ha}^{-1}\right)$ with lower GHG emission intensity $\left(231 \mathrm{~kg} \mathrm{CO}_{2} \mathrm{eq} \mathrm{Mg}^{-1}\right.$ of grain) (Grassini and Cassman, 2012).

In the future, yields must be doubled to meet the growing food demands of an ever-increasing population, without further compromising environmental integrity; therefore, new frontiers for food and environmental sustainability must be created (from point C to D in Fig. 2). Most see this pathway being met by genetically modified crops (Phillips, 2010). Yet obtaining substantially higher yields without further depleting soils, destroying natural habitats, and polluting air and water will demand a comprehensive approach. (Zhang et al., 2013). In reality, pushing the boundaries of productivity will likely evolve from the synergies between novel plant genetics, innovative management technologies, and increasing soil fertility (Keating et al., 2010). Moving millions of smallholder farmers to new productivity and environmental protection paradigms will require research into, and the delivery of, new technologies that increase production at much the same level of investment.

\section{Conclusions}

The current relationship between wheat yield and GHG emissions due to farmers' practices can be reversed for highyielding systems using innovative management technologies, and a new paradigm of productivity and environmental sustainability can be created to produce higher yields while reducing GHG emissions. In this study, we increased yield by $39 \%$ and reduced GHG emission intensity by $41 \%$, compared to current practices. In the future, there will need to be an eco-efficiency agricultural revolution, with large increases in grain yields complemented with reduced GHG emissions. A win-win outcome for agriculture and emissions will require eco-efficient solutions that create new productivity and environmental frontiers to achieve food and GHG security.

\section{Supplementary material related to this article is available online at http://www.biogeosciences.net/11/ 2287/2014/bg-11-2287-2014-supplement.pdf.}

Acknowledgements. This work was funded by the Special Fund for the Agricultural Profession (201103003), the Program for New Century Excellent Talents in University (NCET-11-0478), and the Innovation Group Grant of the National Natural Science Foundation of China (31121062).

Edited by: Z. Jia

\section{References}

Berry, P. M., Kindred, D. R., and Paveley, N. D.: Quantifying the effects of fungicides and disease resistance on greenhouse gas emissions associated with wheat production, Plant Pathol., 57, 1000-1008, 2008.

Burney, J. A., Davis, S. J., and Lobell, D. B.: Greenhouse gas mitigation by agricultural intensification, P. Natl. Acad. Sci. USA, 107, 12052-12057, 2010.

Carberry, P. S., Liang, W. L., Twomlow, S., Holzworth, D. P., Dimes, J. P., McClelland, T., Huth, N. I., Chen, F., Hochman, Z., and Keating, B. A.: Scope for improved eco-efficiency varies among diverse cropping systems, P. Natl. Acad. Sci. USA, 110, 8381-83866, 2013.

Cassman, K. G.: Ecological intensification of cereal production systems: yield potential, soil quality, and precision agriculture, $\mathrm{P}$. Natl. Acad. Sci. USA, 96, 5952-5959, 1999.

Cassman, K. G., Dobermann, A., Walters, D. T., and Yang, H.: Meeting cereal demand while protecting natural resources and improving environmental quality, Annu. Rev. Environ. Resour., 28, 315-358, 20023.

Cerrato, M. E. and Blackmer, A. M.: Comparison of models for describing corn yield response to nitrogen fertilizer, Agron. J., 82, 138-143, 1990.

Chen, X. P., Cui, Z. L., Vitousek, P. M., Cassman, K. G., Matson, P. A., Bai, J. S., Meng, Q. F., and Hou, P.: Integrated soil-crop 
system management for food security, P. Natl. Acad. Sci. USA, 108, 6399-6404, 2011.

Conant, R. T., Ogle, S. M., Paul, E. A., and Paustian, K.: Measuring and monitoring soil organic carbon stocks in agricultural lands for climate mitigation, Front. Ecol. Environ., 9, 169-173, 2010.

Cui, Z. L., Zhang, F. S., Chen, X. P., Miao, Y. X., Li, J. L., Shi, L. W., Xu, J. F., Ye, Y. L., Liu, C., Yang, Z., Zhang, Q., and Huang, S.: On-farm evaluation of an in-season nitrogen management strategy based on soil $\mathrm{N}_{\text {min }}$ test, Field Crop Res., 105, 4855, 2008.

Cui, Z. L., Chen, X. P., and Zhang, F. S.: Current nitrogen management status and measures to improve the intensive wheat-maize system in China, Ambio, 39, 376-384, 2010.

Cui, Z. L., Yue, S. C., Wang, G. L., Meng, Q. F., Wu, L., Yang, Z. P., Zhang, Q., Li, S. Q., Zhang, F. S., and Chen, X. P.: Closing the yield gap could reduce projected greenhouse gas emissions: a case study of maize production in China, Glob. Change Biol., 19, 2467-2477, 2013a.

Cui, Z. L., Yue, S. C.,Wang, G. L., Zhang, F. S., and Chen X. P.: Inseason root-zone $\mathrm{n}$ management for mitigating greenhouse gas emission and reactive $\mathrm{N}$ losses in intensive wheat production, Environ. Sci. Technol., 47, 6015-6022, 2013b.

FAO: FAOSTAT Database, http://faostat3.fao.org/faostat-gateway/ go/to/download/Q/QC/E (last access: 15 May 2013), 2013.

Foley, J. A., Ramankutty, N., Brauman, K. A., Cassidy, E. S., Gerber, J. S., Johnston, M., Mueller, N. D., and O' Connell, C.: Solutions for a cultivated planet, Nature, 478, 337-342, 2011.

Grassini, P. and Cassman, K. G.: High-yield maize with large net energy yield and small global warming intensity, P. Natl. Acad. Sci. USA, 109, 1074-1079, 2012.

Hoben, J. P., Gehl, R. J., Millar, N., Grace, P. R., and Robertson, G. P.: Nonlinear nitrous oxide $\left(\mathrm{N}_{2} \mathrm{O}\right)$ response to nitrogen fertilizer in on-farm corn crops of the US Midwest, Glob. Change Biol., 17, 1140-1152, 2011.

IFA: International Fertilizer Industry Association, http://www. fertilizer.org/ (last access: 1 May 2012), 2012.

IPCC (Intergovernmental Panel on Climate Change): Agriculture, forestry and other land use, in: 2006 IPCC Guidelines for National Greenhouse Gas Inventories, Prepared by the National Greenhouse Gas Inventories Programme edited by: Eggelston, S., Buendia, L., Miwa, K., Ngara, T., and Tanabe, K., IGES, Japan, 2006.

IPCC (Intergovernmental Panel on Climate Change): Mitigation of Climate Change. Summary for Policy Makers. Working Group 3 - 4th Assessment Report, Geneva, Switzerland, 36 pp., 2007.

IPNI Crop Nutrient Response Tool http://nane.ipni.net/article/ NANE-3068 (last access: 20 April 2014), 2014.

Keating, B. A., Peter S., Carberry, P. S., Prem, S., Bindraban, P. S., Senthold Asseng, S., Meinkee, H., and Dixon, J.: Eco-efficient agriculture: concepts, challenges, and opportunities, Crop Sci., 50, 109-117, 2010.

Matson, P. A., Parton, W. J., Power, A. G., and Swift, M. J. Agricultural intensification and ecosystem properties, Science, 277, 504-509, 1997.
McSwiney, C. P. and Robertson, G. P.: Nonlinear response of $\mathrm{N}_{2} \mathrm{O}$ flux to incremental fertilizer addition in a continuous maize (Zea mays L.) cropping system, Glob. Change Biol., 11, 1712-1719, 2005.

Meng, Q., Yue, S., Chen, X., Cui, Z., Ye, Y., Ma, W., Tong, Y., and Zhang, F.: Understanding dry matter and nitrogen accumulation with time-course for high-yielding wheat production in China, Plos One, 8, e68783, doi:10.1371/journal.pone.0068783, 2013.

Millar, N., Robertson, G., Grace, P., Gehl, R., and Hoben, J.: Nitrogen fertilizer management for nitrous oxide $\left(\mathrm{N}_{2} \mathrm{O}\right)$ mitigation in intensive corn (Maize) production: an emissions reduction protocol for US Midwest agriculture, Mitig. Adapt. Strateg. Glob. Change, 15, 185-204, 2010.

Phillips, R. L.: Mobilizing science to break yield barriers, Crop Sci., 50, 99-108, 2010.

Robertson, G. P. and Vitousek, P. M.: Nitrogen in agriculture: Balancing the cost of an essential resource, Annu. Rev. Environ. Resourc., 34, 97-125, 2009.

S.A.S Institute: SAS user's guide: Statistics, SAS Institute, Cary, NC, 1998.

Smith, P., Martino, D., Cai, Z., Gwary, D., Janzen, H., Kumar, P., Mccarl, B., and Ogle, S.: Agriculture, in: Climate Change 2007: Mitigation. Contribution of Working Group III to the Fourth Assessment Report of the Intergovernmental Panel on Climate Change, edited by: Metz, B., Davidson, O. R., Bosch, P. R., Dave, R., and Meyer, L. A., Cambridge University Press, Cambridge, United Kingdom and New York, NY, USA, 2007.

Snyder, C. S., Bruulsema, T. W., Jensen, T. L., and Fixen, P. E.: Review of greenhouse gas emissions from crop production systems and fertilizer management effects, Agr. Ecosys. Environ., 133, 247-266, 2009.

Swaminathan, M. S.: An evergreen revolution, Biologist, 47, 85-89, 2000.

Tilman, D., Cassman, K. G., and Matson, P. A.: Agricultural sustainability and intensive production practices, Nature, 418, 671678, 2002.

Tilman, D., Balzer, C., Hill, J., and Befort, B. L.: Global food demand and the sustainable intensification of agriculture, P. Natl. Acad. Sci. USA, 108, 2026-20264, 2011.

Van Groenigen, J. W., Velthof, G. L., Oenema, O., Van Groenigen, K. J., and Van Kessel, C.: Towards an agronomic assessment of $\mathrm{N}_{2} \mathrm{O}$ emissions: a case study for arable crops, Eur. J. Soil Sci., 61, 903-913, 2010.

Xu, Z. Z., Yu, Z. W. and Zhao, J. Y.: Theory and application for the promotion of wheat production in China: past, present and future, J. Sci. Food Agr., 93, 2339-2350, 2013.

Yue, S. C., Meng, Q. F., Zhao, R. F., Ye, Y. L., Zhang, F. S., Cui, Z. L., and Chen, X. P.: Change in nitrogen requirement with increasing grain yield for winter wheat, Agron. J., 104, 1-7, 2012.

Zhang, F. S., Cui, Z. L., Chen, X. P., Ju, X. Y., Shen, J. B., Chen, Q., and Liu, X. J.: Integrated nutrient management for food security and environmental quality in China, Adv. Agron., 116, 1-40, 2012.

Zhang, F. S., Chen, X. P., and Vitousek, P.: An experiment for the world, Nature, 497, 33-35, 2013. 